\title{
Classification, description and mapping of the vegetation in Khutse Game Reserve, Botswana
}

\author{
T. Lori ${ }^{1}$, M.K. Ditlhogo ${ }^{1}$, M.P. Setshogo ${ }^{1}$ and P. Koosaletse-Mswela ${ }^{2}$ \\ ${ }^{1}$ Department of Biological Sciences, University of Botswana, Gaborone, Botswana \\ ${ }^{2}$ Department of Environmental Science, University of Botswana, Gaborone, Botswana
}

\section{ARTICLE INFORMATION}

\author{
Keywords \\ Khutse Game Reserve \\ Phytosociology \\ Braun-Blanquet \\ Relevés \\ Classification \\ Plant communities
}

Article History:
$\begin{array}{ll}\text { Submission date: } & \text { 01 Aug. } 2018 \\ \text { Revised: } & \text { 06 Jun. } 2019 \\ \text { Accepted: } & \text { 12 Jul. } 2019 \\ \text { Available online: } & \text { 24 Sept. } 2019 \\ \text { https://bojaas.buan.ac.bw }\end{array}$

\section{Corresponding Author:}

$$
\begin{aligned}
& \text { T. Lori } \\
& \text { : }:(+267) 3552605 \\
& \text { 嵒 }: \text { (+267) } 3185097 \\
& \text { : tshololori@gmail.com }
\end{aligned}
$$

Abstract: There is currently no detailed classification and description of plant communities in Khutse Game Reserve (KGR), Botswana, using phytosociological techniques. The main aim of this study was to classify and describe plant communities in KGR. Classification and description of plant communities will help in understanding the plant ecology of KGR. Braun-Blanquet sampling method was applied in 91 stratified random relevés. Nine plant communities were identified and classified using Modified TWINSPAN which is contained in JUICE program. The results showed that there was a statistically significant difference in percentage cover of herbaceous plants between the different plant communities. Schmidtia pappophoroides-Stipagrostis uniplumis and Heliotropium lineare-Enneapogon desvauxii communities had higher cover (\%) of herbaceous plants than other communities. Catophractes alexandri-Stipagrostis uniplumis community had the highest cover (\%) of shrubs. There was no statistically significant difference in plant species diversity (Shannon-Wienner Index) and species evenness between plant communities, but there was a statistically significant difference in plant species richness between the different plant communities. Dichrostachys cinerea-Grewia flava community, Senegalia mellifera subsp. detinens-Maytenus species community and Catophractes alexandri-Stipagrostis uniplumis community had lower number of species, whereas Vachellia luederitzii var. retinens-Grewia flava community had the highest number (46) of plant species. This study will help the Department of Wildlife and National Parks (DWNP) to develop an updated and informed Management Plan for the reserve, which takes cognizance of the plant ecology of the reserve.

\section{Introduction}

Khutse Game Reserve (KGR) is a protected nature reserve situated in the northern part of the Kweneng District, Botswana. KGR is located about $220 \mathrm{~km}$ to the north-west of Gaborone and south of the Central Kalahari Game Reserve (CKGR). According to DWNP (2003), KGR was officially declared a protected area in 1971 and was gazetted in order to protect wildlife and natural resources around fossil valleys and pans that extended from the CKGR. Even though there are no rivers in KGR, the reserve is a habitat of fossil dunes, rolling grasslands, grassed and bare pans and (Pfotenhauer 2009). It is located in a semi-arid Kalahari environment with savanna vegetation which is made up of a spatially complex and structurally heterogeneous mixture of woody and herbaceous species (Mishra and Crews 2014). Maintaining biodiversity and increasing plant species diversity is the main aim of rangeland managers in many semi-arid environments (Fulbright 1996). By their nature, savannas are found in places with dry winters and wet summers and they are located in the tropics between the arid regions and the equatorial forests (Skarpe 1996). Savannas are made up of different life forms of grasses, shrubs and trees and the reasons for the coexistence of these life forms and their importance in conservation and management have been widely documented (Furley 2007). In agreement, Skarpe (1996) states that savannas are characterised by herbaceous vegetation (more especially perennial grasses) and trees and/ or 
shrubs. The savanna biome is normally unstable and influenced by rainfall variability, fire and herbivory thus making the tree-grass ratio to be changeable (Huntley and Walker 1982; Scholes and Walker 1993; Furley 2010). In Africa, savannas exist due to the impact of large herbivores and fire (Skarpe 1992).

Recently, plant ecology of savannas has enabled researchers to understand species composition and functioning, as well as showing their complexity and dynamic nature (Furley 2010). Savannas seem to follow a pattern of succession before it is interrupted by disturbance (Furley 2010). In this debate, Gillson (2004) suggests that at different scales, tree abundance is dominated by various ecological processes and this leads to a concept of patch dynamics that varies spatially and temporally. Wiegand et al. (2003; 2005; 2006) and Meyer et al. (2009) also support the patch dynamics theory while Nicholas et al. (2009) favour soil-fire-vegetation feedback loops. Scholes et al. (2002) suggested that aridity and fire are the two inversely correlated factors which control shrub cover in the Kalahari savanna. When aridity increases, woody plants decrease, to the point where rainfall at below 300 $\mathrm{mm}$ per annum, most woody plants are below $2.5 \mathrm{~m}$ threshold which is used to differentiate trees from shrubs (Scholes et al. 2002). In most cases, woody shrubs found in the moister places do not reach tree height due to fire which intensifies during the dry season when there is increased grass production. Currently, patch dynamics theory appear to be the most favourable (Furley 2010).

KGR supports both resident and migratory populations of large mammalian herbivores. It experienced the same challenges that were observed in the CKGR, whereby very high mortalities of migratory wildlife species were recorded during the 1982-1986 droughts. An intervention by the Government of Botswana was to drill three boreholes between 1986 and 1990 to provide water to wildlife in the game reserve (DWNP staff, pers. comm.). This was part of the same measures that were made for CKGR, where nine boreholes were developed (Makhabu et al. 2002). Each of the three boreholes in KGR supplies an artificial water point and these water points are located at Khutse 1 Pan, Moreswe Pan and Molose Pan.

The discipline of vegetation science (plant ecology) was developed in the $20^{\text {th }}$ century and most European plant ecologists were interested in phytosociology (phyto meaning plant and sociology meaning groupings of species) (Brown et al. 2013). The classification, description and mapping of vegetation in game reserves have gained a wider interest in plant ecology. Recently, the demand for data acquired from vegetation studies has increased especially in the discipline of biodiversity conservation and environmental monitoring (Chytrý et al. 2011). Due to climate change, studies on phytosociology are very crucial since vegetation data can be used to determine how plant communities respond to environmental changes over time (Brown et al. 2013). Vegetation surveys and classifications are also crucial in basic research of plant ecology and they give information for describing vegetation types and understanding various ecosystems (Chytrý et al. 2011). In a protected nature reserve, it is very important to understand plant communities in order to come up with conservation strategies (Daemane et al. 2010). Since the 1990s, vegetation studies have attracted some interest because of an increase in demand from experts in the field of nature conservation to come up with comprehensive systems of vegetation or habitat classifications which are needed for conservation planning and making well informed management decisions (Chytrý et al. 2011). Another reason for the interest is that there have been huge advances in technology which aid in the establishment and management of electronic databases that enable vegetation data collected from past decades to be converted into formats that can be accessed and analysed with ease (Schaminée et al. 2009; Chytrý et al. 2011; Dengler et al. 2011).

In South Africa, numerous phytosociological studies have been carried out in natural protected areas such as national parks and privately owned game reserves and these studies have produced many publications on vegetation of protected areas in various biomes (Brown et al. 2013). The description and mapping of vegetation has played a crucial role in classifying and interpreting various complex ecosystems and in simplifying their spatial and temporal complexity (Mucina and Rutherford 2006; Brown et al. 2013). There is a need to conserve biodiversity and it is crucial to develop wildlife management plans that are efficient, ecologically sound and scientifically based (Bezuidenhout 1994; 2009). The natural resources can be used sustainably if the vegetation of the reserve is grouped into plant communities (Bezuidenhout 2009). In natural areas, ecosystems are represented by plant communities which serve as a basis of any management plan (Brown et al. 2005). When there is information on plant communities, and their distribution is well known, it will be easy to find habitats that are suitable for herbivores since different species of animals use different plant communities for shelter, food and reproduction (Brown et al. 2005; Woldewahid et al. 2007).

There is currently no detailed classification and description of plant communities in KGR using phytosociological techniques. Vegetation data collected through phytosociological methods can be 


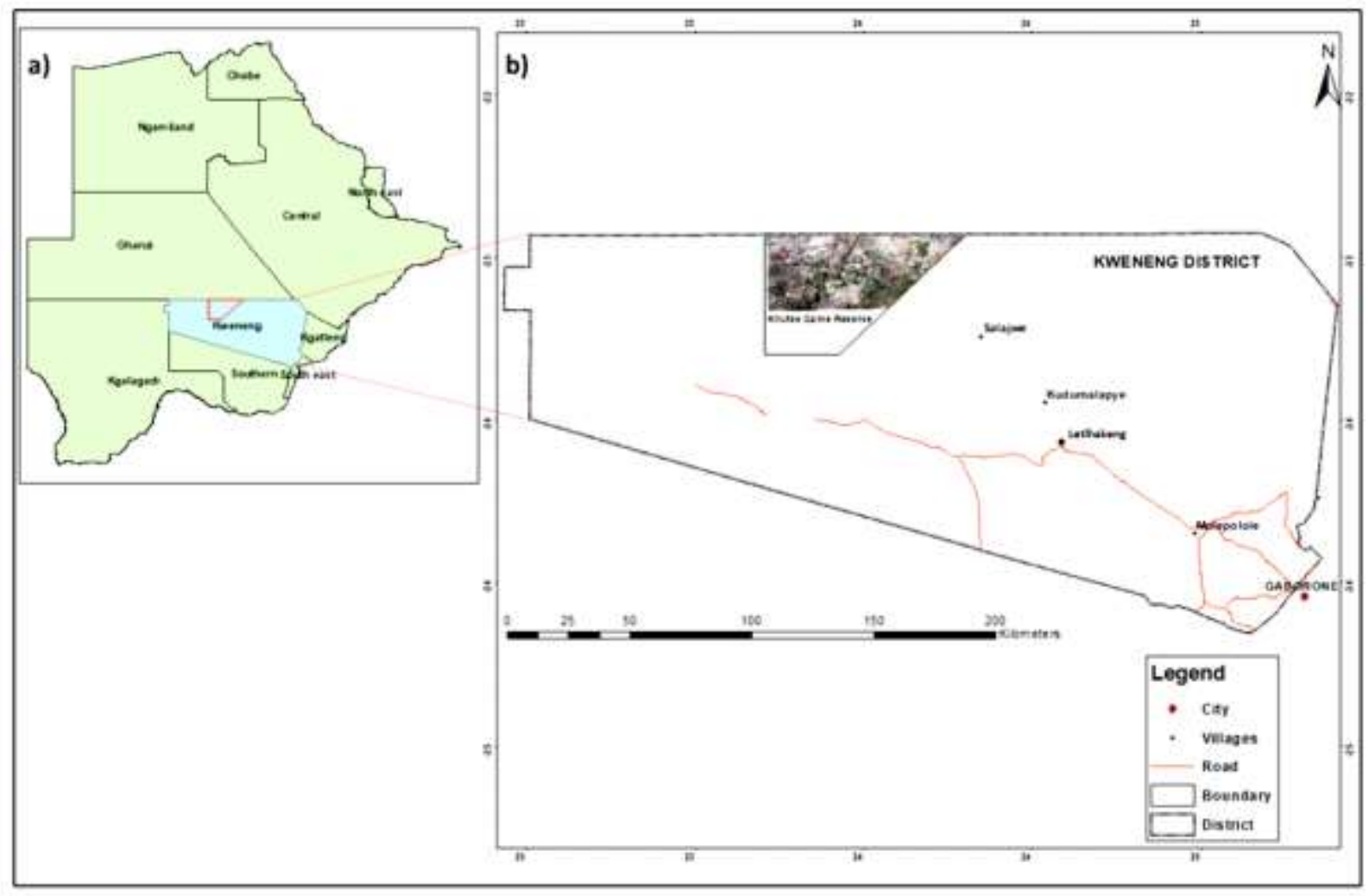

Fig. 1: a) Map of Botswana indicating the location of KGR (red square) in Kweneng District, b) Map of Kweneng District showing KGR with an overlay of Sentinel-2A natural color RGB (red, green and blue) imagery of the study area.

utilised in availing detailed information on the abundance of plant species, describing vegetation structure and determining plant species diversity, plant succession and production of different ecosystems (Brown et al. 2013). Vegetation studies also help in finding out areas that are ecologically sensitive, threatened by bush encroachment, degraded, habitats for rare or endangered plant and animal species (Zietsman and Bredenkamp 2006). The main aim of this study was to classify and describe plant communities in KGR. The study is crucial because it is the basis of ecological classification of plant communities in KGR, and will also be a long term record of the characteristics of the vegetation in each plant community.

\section{Description of Study Site}

The research was conducted in KGR which is situated in northern Kweneng District, Botswana (Fig. 1) and is about $220 \mathrm{~km}$ north-west of Gaborone. It is on the south of the Central Kalahari Game Reserve (CKGR) and is located between latitude $23^{\circ} \mathrm{S} \& 24^{\circ} \mathrm{S}$ and longitude $23^{\circ} \mathrm{E} \& 25^{\circ} \mathrm{E}$, at an average altitude of $1000 \mathrm{~m}$ above sea level. KGR is $2600 \mathrm{~km}^{2}$ in size and was officially declared a protected area in 1971 (Weilenmann et al. 2010; DWNP 2003). There has not been any detailed ecological study done on the vegetation of KGR (DWNP staff, pers. comm.).

\section{Climate}

The climate of KGR is semi-arid with very cold and dry winter (May-September) and a very hot and wet summer (October-April) (DWNP 2003; Weilenmann et al. 2010). July average temperature is $13-14^{\circ} \mathrm{C}$ and January average temperature is $25-26^{\circ} \mathrm{C}$ (Zehnder 2015). The mean annual rainfall is $321 \pm 67 \mathrm{~mm}$ and most of the rain falls between December and April (DWNP 2003; Weilenmann et al. 2010).

\section{Geomorphology and soils}

KGR is a flat area characterized by Kalahari sandveld with sandy soils and fossil dunes outside the pans (Makhabu et al. 2002; Pfotenhauer 2009; Weilenmann et al. 2010). These sandy soils are deep, yellowish to reddish in colour and they drain quickly (de Wit \& Nachtergaele 1990). There are fossil river valleys in KGR as well as some bare and grassed pans (Makhabu et al. 2002). The artificial water points in KGR are located at Khutse 1 Pan, Moreswe Pan and Molose Pan. The three major soil factors that influence the distribution of plants in all Kalahari habitat types are surface soil clay content, sub-surface hardpan layers and calcrete beds and 
catena position (DWNP 2003). The pans are mainly calcrete and have a high content of clay soils with high mineral content and they retain moisture very well (DHV 1980; Makhabu et al. 2002).

\section{Animals}

KGR has mammalian herbivores and these include springbok (Antidorcas marsupialis), kudu (Tragelaphus strepsiceros), gemsbok (Oryx gazelle) and giraffe (Giraffa camelopardis). Carnivores include lions (Panthera leo), leopards (Panthera pardus) and black-backed jackal (Canis mesomelas). The birds which are found in KGR include ostrich (Struthio camelus), Kori bustard (Ardeotis kori), eagle (Hieraatus spilogaster), lappet faced vulture (Torgos tracheliotos), and southern pied babbler (Turdoides bicolor) (DWNP 2003).

\section{Habitat and Vegetation}

DHV (1980) identified four major habitat types of the Kalahari and described them as follows: (i) Fossil river valley and pan habitat: This habitat has a high content of clay soils and this leads to predominance of grassland mixed with occasional clumps of trees called tree islands. Shrub communities predominate in areas where sands overlay pan and valley floors. (ii) Dune habitat: In dunes, there is a mixture of woodland, shrub and grassland. The upper dune slopes and crests have coarse sands for easy root penetration and they are often covered with trees, whereas the lower slopes have compacted sands and they promote growth of shrubs and grasses. (iii) Interdunal habitat: This habitat has smaller sand particles and patchy sub-surface hardpan layers that promote access to water near the soil surface by the roots of shrubs and grasses. The interdunal habitat forms a mosaic with the dune habitat. (iv) Plain habitat: The plain habitat has smaller soil particles which do not promote penetration by tree roots and it lacks compacted sub-surface soil layers which hinders the availability of moisture near the soil surface. A study by Mishra et al. (2015) broadly and physiognomically defined six vegetation morphology classes in the neighbouring CKGR as (i) woodland, (ii) dense shrubland, (iii) open shrubland, (iv) very open shrubland, (v) grassland and (vi) pan.

The plant species which are found in KGR include trees such as Philoneptera nelsii (Schinz) Schrire, Senegalia erubescens Welw. ex Oliv. Senegalia mellifera subsp. detinens (Burch.) Brenan, Boscia albitrunca (Burch.) Gilg \& Gilg-Ben., Ziziphus mucronata Willd. and Terminalia sericea Burch. ex DC. Shrubs consist of Greiwa flava DC., Gardenia volkensii K. Schum., Catophractes alexandri D. Don, Dichrostachys cinerea (L.) Wight \& Arn., Pentzia calva S. Moore and Rhigozum brevispinosum Kuntze. Grasses include Schmidtia pappophoroides Steud. ex J.A. Schmidt, Stipagrostis uniplumis (Licht.) De Winter, Brachiaria humidicola (Rendle) Schweick and Enneapogon desvauxii P. Beauv. Herbs include Chloris virgate Sw., Limeum sulcatum (Klotzsch) Hutch., Panicum maximum Jacq., Chamaesyce inaequilatera (Sond.) Soják and Commelina diffusa Burm.f.

\section{Materials and Methods}

A reconnaissance of the study area was done on the $13^{\text {th }}-15^{\text {th }}$ November 2015 inorder to determine homogeneous areas in the vegetation. Google earth images and driving surveys were used to stratify the area into physiognomic-physiographic units in order to identify homogenous vegetation types. The main vegetation sampling was conducted in summer from the $2^{\text {nd }}$ March to the $12^{\text {th }}$ May 2016 when there was optimal vegetation growth. Vegetation cover was determined by means of the Braun-Blanquet method (Braun-Blanquet 1932). The Braun-Blanquet method was selected because it needs one third to one fifth the time required for stem-counts (Wikum and Shanholtzer 1978).

Plots were arranged along transects which ran parallel to the tracks for easy access and they were randomly located within the different homogenous units. Inorder to avoid road edge effects, plots were located at a minimum distance of $50 \mathrm{~m}$ away from the tracks. The vegetation was divided into herbaceous layer (grasses and herbaceous species), shrub layer (woody species between 0-3m) and tree layer (woody species $>3 \mathrm{~m}$ ) as in Bezuidenhout (2009). Sampling plots of $10 \mathrm{~m} \times 10 \mathrm{~m}$ were marked with range poles. These plots were used for recording trees and shrubs. Four $1 \mathrm{~m} \times 1 \mathrm{~m}$ quadrats were randomly located inside the $10 \mathrm{~m} \times 10 \mathrm{~m}$ plot for recording herbaceous vegetation. In each sampling plot, i.e., the large $10 \mathrm{~m} \times 10 \mathrm{~m}$ plot and each of the four $1 \mathrm{~m} \times 1 \mathrm{~m}$ smaller plots, all plant species were recorded to determine species composition. The cover and height of the vegetation were also determined.

Cover data was based on the Braun-Blanquet cover estimation classes whereby $\mathbf{1}$ is cover between $1-5 \%, 2$ is cover between $5-25 \%, 3$ is cover between $25-50 \%, \mathbf{4}$ is cover between $50-75 \%$ and $\mathbf{5}$ is cover more than 75\% (Braun-Blanquet 1932; MuellerDombois and Ellenberge 1974). A 5m telescopic levelling rod was used to measure the height of trees and shrubs. A handheld Global Positioning System (Garmin GPS64S) was used to mark the location of each sampling plot. Other environmental factors that were recorded included altitude, habitat type and soil colour. Munsell Soil Colour Chart was used for identifying soil colour. A NIKON D5200 digital camera was used to take pictures of the plant communities. Plant species were pressed and taken to 
the University of Botswana Herbarium for verification and identification. Plant species names follow Setshogo and Venter (2003), Kabelo and Mafokate (2004), Setshogo (2005) and van Oudtshoorn (2009).

\section{Data Analysis}

SPSS 24 was used for statistical analysis. Percentage cover data were arcsine transformed in order to try stretching out both the tails and compress the middle part of the distribution (Sokal and Rohlf 1969). Shapiro-Wilk test was used to test for normality of the data. Data on arcsine transformed cover were not normally distributed $(\mathrm{p}<0.05)$ Therefore, nonparametric statistics were used to analyse the data. Modified TWINSPAN (Roleček et al. 2009), which is contained in JUICE 7.0.102 program (Tichý 2002), was used to classify plant communities. The Braun-Blanquet scale (1, 2, 3, 4 and 5) was used and the scale values were converted into percentages as $3,13,38,63$, and 88 . The values of pseudospecies cut levels were $0,5,25,50$ and 75 with minimum group size of 6 . The type of fidelity measure used was phi coefficient. Phi coefficient was chosen because it uses presence/ absence data and does not depend on the size of the data (Chytrý et al. 2002). The size of all groups was standardized to equal size and the size of the target group was $40 \%$ of the total data set. Fisher's exact test was calculated and plant species with significance $\mathrm{p}<0.05$ were diagnostic. Fidelity threshold was set to 40 lower and 80 higher, frequency threshold set to 60 lower and 80 higher, and cover threshold set to 50 lower and 80 higher. Species richness, Shannon-Wienner diversity index and species evenness were calculated in JUICE 7.0.102 program (Tichý 2002).

\section{Results}

\section{Classification of Plant Communities}

Nine plant communities were classified by modified TWINSPAN analysis. Table 1 lists the communities according to how modified TWINSPAN grouped them. The classification results are also presented in a synoptic table and dendrogram (Table 2 and Figure 2 , respectively). Figure 3 shows plant communities of KGR and the number of relevés in which photos were taken from.

Table 1: Plant communities of KGR with their number of relevés sampled. Total number of relevés is 91.

\begin{tabular}{|c|c|c|c|}
\hline Group & Plant community & $\begin{array}{l}\text { Number of } \\
\text { relevés }\end{array}$ & Relevé numbers \\
\hline 1 & $\begin{array}{l}\text { Heliotropium lineare-Enneapogon desvauxii } \\
\text { community }\end{array}$ & 10 & 82876783766591709078 \\
\hline 2 & Senegalia mellifera-Maytenus species community & 4 & 4156886 \\
\hline 3 & $\begin{array}{l}\text { Senegalia erubescens-Philoneptera nelsii } \\
\text { community }\end{array}$ & 15 & $\begin{array}{l}67934396043491119384775 \\
312132\end{array}$ \\
\hline 4 & $\begin{array}{l}\text { Brachiaria humidicola-Philoneptera nelsii } \\
\text { community }\end{array}$ & 6 & 75384541336 \\
\hline 5 & Terminalia sericea-Philoneptera nelsii community & 17 & $\begin{array}{l}747240417377466429626356 \\
5230123335\end{array}$ \\
\hline 6 & Dichrostachys cinerea-Grewia flava community & 3 & 166669 \\
\hline 7 & $\begin{array}{l}\text { Catophractes alexandri-Stipagrostis uniplumis } \\
\text { community }\end{array}$ & 6 & 123144457 \\
\hline 8 & $\begin{array}{l}\text { Vachellia luederitzii var. retinens-Grewia flava } \\
\text { community }\end{array}$ & 14 & $\begin{array}{l}24888158259176155222371 \\
8026\end{array}$ \\
\hline 9 & $\begin{array}{l}\text { Schmidtia pappophoroides-Stipagrostisuniplumis } \\
\text { community }\end{array}$ & 16 & $\begin{array}{l}581018202728374245485051 \\
598589\end{array}$ \\
\hline
\end{tabular}


Table 2: Percentage synoptic table of 91 relevés of KGR plant communities. Diagnostic species have fidelity measure (phi coefficient $\mathrm{x} 100)$ of over 40.0 and significant fidelity $(\mathrm{P}<0.05$, Fisher's exact test). Dashes represent negative fidelity. Group numbers represent plant communities and they are described in Table 1.

\section{Group No.}

No. of relevés

Diagnostic species of Group 1

Heliotropium lineare

Enneapogon desvauxii

Tarchnanthus camphoratus

Limeum sulcatum

Urochloa trichopus

Diagnostic species of Group 2

Senegalia mellifera subsp. detinens

Maytenus species

Ziziphus mucronata

Commelina diffusa

Setaria verticillata

Hibiscus trionum

Chamaesyce inequilatera

Diagnostic species of Group 3

Senegalia erubescens

Diagnostic species of Group 4

Brachiaria humidicola

Digitaria pentzii

Commelina africana

Diagnostic species of Group 5

Anthephora pubescens

Eragrostis pallens

Diagnostic species of Group 6

Aptosimum procumbens

Diagnostic species of Group 7

Catophractes alexandri

Diagnostic species of Group 8

Vachellia luederitzii var. retinens

Diagnostic species of Group 9

Schmidtia pappophoroides

Common diagnostic species of two or three communities

Terminalia sericea

Dichrostachys cinerea

Gardenia volkensii

Rhigozum brevispinosum

Grewia flava

Philoneptera nelsii

$\begin{array}{lllllllll}1 & 2 & 3 & 4 & 5 & 6 & 7 & 8 & 9 \\ 10 & 4 & 15 & 6 & 17 & 3 & 6 & 14 & 16\end{array}$

$\begin{array}{lllllllll}87.7 & - & - & - & - & - & - & - & - \\ 79.6 & - & - & - & - & - & - & - & - \\ 45.2 & - & - & - & - & - & - & - & - \\ 43.1 & - & - & - & - & - & - & - & - \\ 43.1 & - & - & - & - & - & - & - & -\end{array}$

$\begin{array}{lllllllll}- & 79.4 & - & - & - & - & - & - & 25.4 \\ - & 70.7 & - & - & - & - & - & - & - \\ - & 59.8 & - & - & - & - & - & - & - \\ - & 40.8 & - & - & - & - & - & - & - \\ - & 40.8 & - & - & - & - & - & - & - \\ - & 40.8 & - & - & - & - & - & - & - \\ - & 40.8 & - & - & - & - & - & - & -\end{array}$

一 $\quad$ - $80.0 \quad-\quad-\quad-\quad-\quad-$

$\begin{array}{lllllllll}- & - & - & 72.5 & - & - & - & - & - \\ - & - & - & 48.0 & - & - & - & - & - \\ - & - & - & 41.3 & - & - & - & - & -\end{array}$

$\begin{array}{lllllllll}- & - & - & - & 45.1 & - & - & - & - \\ - & - & - & - & 44.7 & - & - & - & -\end{array}$

- $-\quad-\quad-\quad-\quad \begin{array}{lllll}- & 48.0 & - & -\end{array}$

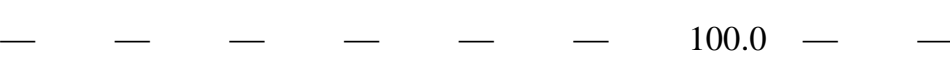

- $-\quad-\quad-\quad-\quad-\quad-52.7$

64.7

$\begin{array}{lllllllll}- & - & - & 52.3 & 56.4 & - & - & - & - \\ - & - & - & 48.2 & - & 83.6 & - & - & - \\ - & - & - & - & - & - & 50.5 & 42.8 & - \\ - & - & - & - & - & - & - & 41.9 & 41.9 \\ - & - & - & - & - & - & - & 45.6 & 33.3 \\ - & - & 45.3 & 56.2 & 48.7 & - & - & - & -\end{array}$ 


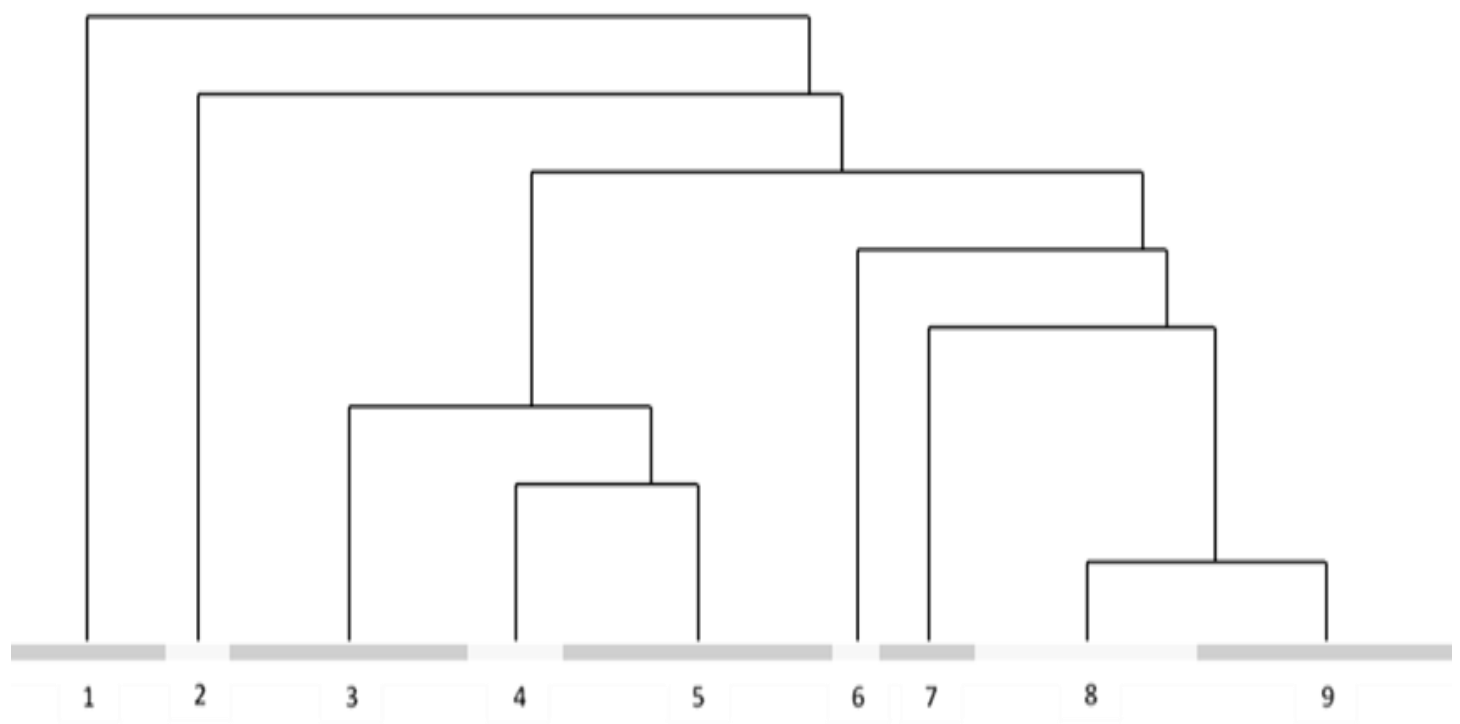

Fig. 2: Cluster analysis dendrogram of KGR plant communities. Numbers (1-9) are groups representing plant communities and they are described in Table 1.

\section{Percentage Cover of Herbs, Shrubs and Trees in Plant Communities}

\section{Herbaceous Layer}

Independent samples Kruskal-Wallis $\mathrm{H}$ test showed that there was a statistically significant difference in cover $(\%)$ of herbaceous plants between the different plant communities, $\chi^{2}(8)=18.114, p=0.020$. Catophractes alexandri-Stipagrostis uniplumis community had a minimum mean rank of 47.30 and Schmidtia pappophoroides-Stipagrostis uniplumis and Heliotropium lineare-Enneapogon desvauxii communities had mean ranks of 101.00 and 97.70, respectively. (Figure 4 and Table 3). This shows that the two plant communities had higher cover (\%) of herbaceous plants than other communities.

\section{Shrub Layer}

The results showed that there was no statistically significant difference in cover $(\%)$ of shrubs between the different plant communities, $\chi^{2}(8)=9.320, \mathrm{p}=$ 0.316. In plain habitat, Catophractes alexandriStipagrostis uniplumis community had a highest cover (\%) of shrubs (mean rank of 262.93) and Brachiaria humidicola-Philoneptera nelsii community had a lowest cover (\%) of shrubs (Figure 4) with minimum mean rank of 180.11 (Table 3).

\section{Tree Layer}

There was no statistically significant difference in cover $(\%)$ of trees between the different plant communities, $\chi^{2}(5)=8.102, p=0.151$. Schmidtia pappophoroides-Stipagrostis uniplumis community, with a maximum mean rank of 37.33 , had the highest cover (\%) of trees (Figure 4 and Table 3). Brachiaria humidicola-Philoneptera nelsii community had a minimum mean rank of 16.25 and this shows that this community had the lowest cover (\%) of trees than other plant communities.

\section{Plant Species Richness, Diversity and Evenness of Plant Communities}

One-way ANOVA results showed no statistically significant differences in species diversity (ShannonWeiner Index) between plant communities $\left(\mathrm{F}_{[8,82]}=\right.$ $1.975, \mathrm{p}=0.060)$. Independent samples KruskalWallis $\mathrm{H}$ test showed that there was a statistically significant difference in species richness between the different plant communities, $\chi^{2}(8)=15.733$, $\mathrm{p}=$ 0.046. Dichrostachys cinerea-Grewia flava community, Senegalia mellifera subsp. detinensMaytenus species community and Catophractes alexandri-Stipagrostis uniplumis community had lower species richness of 11, 14 and 16, respectively. Vachellia luederitzii var. retinens-Grewia flava community had a highest number of species richness (Table 4). This plant community also had the highest Euclidean distance, Jaccard and Simpson Betadiversity (Table 5).

The results indicated no statistically significant difference in species evenness between the different plant communities, $\chi^{2}(8)=7.364, \mathrm{p}=0.498$. Brachiaria humidicola-Philoneptera nelsii community had the highest species evenness (Table 4). 
Table 3: Mean ranks of herbaceous, shrubs and trees in KGR plant communities located in pans and plain habitats. Group numbers represent plant communities which are described in Table 1. There were no data for trees in groups 1, 6 and 7.

\begin{tabular}{lllllll}
\hline & \multicolumn{2}{l}{ Herbaceous } & \multicolumn{2}{l}{ Shrubs } & \multicolumn{2}{l}{ Trees } \\
\hline Group & $\mathrm{N}$ & Mean Rank & $\mathrm{N}$ & Mean Rank & $\mathrm{N}$ & Mean Rank \\
1 & 23 & 97.70 & 33 & 198.80 & & \\
2 & 5 & 87.90 & 13 & 205.54 & 5 & 27.5 \\
3 & 27 & 76.30 & 64 & 198.28 & 19 & 23.05 \\
4 & 12 & 68.46 & 32 & 180.11 & 4 & 16.25 \\
5 & 30 & 79.67 & 82 & 199.13 & 11 & 22.73 \\
6 & 2 & 81.75 & 9 & 216.89 & & \\
7 & 10 & 47.30 & 22 & 262.93 & & \\
8 & 22 & 67.16 & 94 & 194.68 & 8 & 34.06 \\
9 & 31 & 101.00 & 54 & 210.27 & 3 & 37.33 \\
Total & 162 & & 403 & & 50 & \\
\hline
\end{tabular}

Table 4: Plant communities of KGR with their number of relevés, number of species, species diversity and evenness. Group numbers represent plant communities which are described in Table 1.

\begin{tabular}{llllll}
\hline Group & $\begin{array}{l}\text { Number of } \\
\text { relevés }\end{array}$ & $\begin{array}{l}\text { Species } \\
\text { richness }\end{array}$ & $\begin{array}{l}\text { Mean no. of } \\
\text { Species/ Plot }\end{array}$ & $\begin{array}{l}\text { Mean Species } \\
\text { Diversity (H') }\end{array}$ & $\begin{array}{l}\text { Mean Species } \\
\text { evenness }\end{array}$ \\
\hline 1 & 10 & 26 & 5.60 & 1.18 & 0.71 \\
2 & 4 & 14 & 5.00 & 1.09 & 0.68 \\
3 & 15 & 35 & 6.53 & 1.48 & 0.79 \\
4 & 6 & 23 & 7.50 & 1.62 & 0.83 \\
5 & 17 & 39 & 6.59 & 1.39 & 0.77 \\
6 & 3 & 11 & 5.00 & 1.06 & 0.69 \\
7 & 6 & 16 & 5.33 & 1.25 & 0.78 \\
8 & 14 & 46 & 8.50 & 1.63 & 0.78 \\
9 & 16 & 26 & 5.38 & 1.21 & 0.74 \\
\hline
\end{tabular}

Table 5: Average Total inertia, Euclidean distance, Whittaker (overall) and Beta-diversity dissimilarity indices within relevés groups. Group numbers represent plant communities which are described in Table 1.

\begin{tabular}{|c|c|c|c|c|c|c|c|c|}
\hline \multicolumn{4}{|c|}{ Data variability } & \multicolumn{5}{|c|}{ Beta-diversity (only presence absence-pair comp.) } \\
\hline Group & $\begin{array}{l}\text { Total } \\
\text { inertia }\end{array}$ & $\begin{array}{l}\text { Euclidean } \\
\text { distance }\end{array}$ & Whittaker & Jaccard & Sorensen & Harrison & Williams & Simpson \\
\hline 1 & 2.97 & 2.644 & 3.643 & 0.767 & 0.641 & 0.275 & 0.203 & 0.486 \\
\hline 2 & 1.525 & 2.484 & 1.800 & 0.763 & 0.641 & 0.208 & 0.171 & 0.458 \\
\hline 3 & 3.83 & 2.863 & 4.357 & 0.770 & 0.641 & 0.412 & 0.278 & 0.555 \\
\hline 4 & 1.925 & 3.074 & 2.067 & 0.779 & 0.648 & 0.416 & 0.276 & 0.547 \\
\hline 5 & 4.485 & 2.938 & 4.920 & 0.798 & 0.679 & 0.386 & 0.267 & 0.591 \\
\hline 6 & 1.153 & 2.562 & 1.200 & 0.800 & 0.677 & 0.292 & 0.215 & 0.528 \\
\hline 7 & 1.955 & 2.530 & 2.000 & 0.752 & 0.615 & 0.353 & 0.249 & 0.507 \\
\hline 8 & 3.946 & 3.431 & 4.412 & 0.821 & 0.708 & 0.414 & 0.282 & 0.618 \\
\hline 9 & 3.012 & 2.416 & 3.837 & 0.709 & 0.563 & 0.316 & 0.224 & 0.429 \\
\hline
\end{tabular}




\section{Naming and Description of Plant Communities}

Diagnostic species (the first name), constant species and dominant species (the second name) obtained from vegetation data analysed in JUICE 7.0.102 program (Tichý 2002) were used to name plant communities. According to Chytrý and Tichý (2003), diagnostic species have a distinct concentration of occurrence or abundance in a particular plant community. Constant species are species of high frequency and dominant species are species of high cover-abundance (Chytrý and Tichý 2003).

1. Heliotropium lineare-Enneanpogon desvauxii community

Heliotropium lineare-Enneapogon desvauxii community is associated with reddish gray soil and it was found in pans of the study area (Figure 3a). The diagnostic species of this community were herbaceous Heliotropium lineare (87.7\% fidelity), grass Enneapogon desvauxii, herbaceous species Limeum sulcatum, shrub Tarchonanthus camphoratus Linnaeus and grass Urochloa trichopus (Hochst.) Stapf (Table 2). The dominant species with each species having 30\% cover were Heliotropium lineare and Enneapogon desvauxii. The other dominant herbaceous species Chloris virgata, Limeum sulcatum, Panicum maximum, shrubs Pentzia calva and Solanum species (smaller fuits) had $10 \%$ cover each. The constant species were Heliotropium lineare and Enneapogon desvauxii with frequency of $90 \%$ and $80 \%$, respectively. The average height of Heliotropium lineare is $0.3 \mathrm{~m}$. The average canopy cover of herbaceous and shrub layers was $36.7 \%$ and $17.2 \%$, respectively (Figure 4). Heliotropium lineare-Enneapogon desvauxii community does not have tree species.

2. Senegalia mellifera subsp. detinens-Maytenus species community

Senegalia mellifera subsp. detinens-Maytenus species community was a tree island situated in pans (Figure 3b). The diagnostic species were shrubs and trees of Senegalia mellifera subsp. detinens $(79.4 \%$ fidelity), shrub Maytenus species, shrubs and trees Zizipus mucrunata, herbaceous species Chamaesyce inaequilatera, herbaceous Commelina diffusa, shrub Hibiscus trionum L., and grass Setaria verticillata (L.) P.Beauv. (Table 2). Senegalia mellifera subsp. detinens was dominant with $50 \%$ cover, whereas Chamaesyce inequilatera, Maytenus species and Setaria verticillata had a cover of $25 \%$ each. The constant species Senegalia mellifera subsp. detinens and Maytenus species had frequency of $100 \%$ and $75 \%$, respectively. The average canopy cover of herbaceous and shrub layers was $31.0 \%$ and $19.9 \%$, respectively (Figure 4).
3. Senegalia erubescens-Philoneptera nelsii community

Senegalia erubescens-Philoneptera nelsii community was a woodland community located in plain habitat (Figure 3c). It was associated with dark brown soil. The diagnostic species were shrubs and trees of Senegalia erubescens $(80 \%$ fidelity) and Philoneptera nelsii (Table 2). The dominant species were Senegalia erubescens (33\% cover) and grass Stipagrostis uniplumis $(27 \%$ cover $)$ Shrub Philoneptera nelsii, herbs Pollichia campestris Aiton and Sansevieria aethiopica Thunb. were also dominant with $7 \%$ cover each. Senegalia erubescens (80\% frequency) and Philoneptera nelsii (73\% frequency) are constant species. The average canopy cover of shrub and tree strata was $15.9 \%$ and $26.2 \%$, respectively (Figure 4).

\section{Brachiaria humidicola-Philoneptera nelsii} community

Brachiaria humidicola-Philoneptera nelsii community was a shrubland community occuring in plain habitat with reddish brown soil (Figure 3d). The diagnostic species were grass Brachiaria humidicola (72.5\% fidelity), shrubs and trees Philoneptera nelsii, Terminalia sericea, Dichrostachys cinerea, grass Digitaria pentzii and herb Commelina africana L. (Table 2). The dominant species were Philoneptera nelsii and grass Eragrostis tef (Zucc.) Trotter with each species having cover of $17 \%$. Philoneptera nelsii (83\% frequency) was a constant species together with Brachiaria humidicola, shrub Dichrostachys cinerea, shrub Grewia flava and shrub Terminalia sericea which have $67 \%$ frequency each. The average canopy cover of herbaceous and tree strata was $18.8 \%$ and $10.5 \%$, respectively (Figure 4).

\section{Terminalia sericea-Philoneptera nelsii community}

Terminalia sericea- Philoneptera nelsii community was a shrubland community found in plain habitat with light brown well drained soil (Figure 3e). The diagnostic species were shrub Terminalia sericea (56.4\% fidelity), shrub Philoneptera nelsii, grass Anthephora pubescens Nees and grass Eragrostis pallens Hack. (Table 2). The dominant species were Philoneptera nelsii, grass Stipagrostis uniplumis and shrub Terminalia sericea with $12 \%$ cover each. Anthephora pubescens, shrub Dichrostachys cinerea, shrub Grewia flava and shrub Vachellia luederitzii var. retinens are also dominant with each species having cover of $6 \%$. The constant species Philoneptera nelsii, Terminalia sericea and Stipagrostis uniplumis had frequency of $76 \%, 71 \%$ and $65 \%$, respectively. The average canopy cover of 
herbaceous, shrub and tree strata was $24.3 \%, 16.0 \%$ and $23.9 \%$, respectively (Figure 4).

\section{Dichrostachys cinerea-Grewia flava community}

Dichrostachys cinerea-Grewia flava community was a shrubland community located in plain habitat with reddish brown soil (Figure 3f). The diagnostic species were shrub Dichrostachys cinerea (83.6\% fidelity) and herb Aptosimum procumbens (Lehm.) Steud. (Table 4.2). The dominant species were Dichrostachys cinerea and herb Talinum species (Thunb.) Eckl. \& Zeyh. and each species has 67\% cover. The constant species were Dichrostachys cinerea (100\% frequency), shrub Grewia flava (67\% frequency), and Talinum species (67\% frequency). The estimated average cover of herbaceous and shrub strata was $33.0 \%$ and $22.4 \%$, respectively (Figure 4). Dichrostachys cinerea-Grewia flava community did not have a tree stratum.

\section{Catophractes alexandri-Stipagrostis uniplumis community}

Catophractes alexandri-Stipagrostis uniplumis community was a closed shrubland community found around pans (Figure $3 \mathrm{~g}$ ). The soil was reddish gray in colour. The diagnostic species were shrub Catophractes alexandri (100\% fidelity) and shrub Gardenia volkensii (Table 2). The dominant species were Catophractes alexandri and shrub Rhigozum trichotomum with a cover of $50 \%$ and $17 \%$, respectively. The constant species are Catophractes alexandri (100\% frequency) and grass Stipagrostis uniplumis (67\% frequency). The average canopy cover of herbaceous and shrub strata was $10.5 \%$ and $30.7 \%$, respectively (Figure 4). This plant community did not have a tree layer.

8. Vachellia luederitzii var. retinens-Grewia flava community

Vachellia luederitzii var. retinens-Grewia flava community was a woodland community situaed in plain habitat (Figure $3 \mathrm{~h}$ ). It was associated with dark reddish gray soil. The diagnostic species were shrubs and trees of Vachellia luederitzii var. retinens (52.7\% fidelity), shrub Grewia flava, shrub Gardenia volkensii and shrub Rhigozum brevispinosum (Table 2). Vachellia luederitzii var. retinens (29\% cover) was dominant, as well as shrub Paveta species, Rhigozum brevispinosum, tree Senegalia mellifera subsp. detinens and grass Stipagrostis uniplumis which have 7\% cover each. The constant species was Grewia flava ( $86 \%$ frequency). The average canopy cover of shrub and tree strata was $14.3 \%$, and $44.3 \%$, respectively (Figure 4).

9. Schmidtia pappophoroides-Stipagrostis uniplumis community
Schmidtia pappophoroides-Stipagrostis uniplumis community was a grassland mixed with shrubs and trees occuring in plain habitat (Figure 3i). It was found in dark yellowish brown soil. The diagnostic species are grass Schmidtia pappophoroides (64.7\% fidelity) and shrub Rhigozum brevispinosum (Table 2). The dominant species were grass Stipagrostis uniplumis $(50 \%$ cover $)$ grass Schmidtia pappophoroides (25\% cover), Rhigozum brevispinosum (6\% cover) and tree Senegalia mellifera subsp. detinens (6\% cover). Schmidtia pappophoroides and Stipagrostis uniplumis grasses were also constant species together with shrub Grewia flava and they have frequency of $75 \%$ each. The average canopy cover of herbaceous, shrub and tree strata was $37.5 \%, 15.3 \%$ and $46.3 \%$, respectively (Figure 4).

\section{Discussion}

Heliotropium lineare-Enneapogon desvauxii community was found in pans. The main pans in KGR are Khutse, Moloswe, Moreswe, Kujwe, Sutswane and Motailane. Artificial boreholes have been constructed by DWNP at Khutse 1, Moloswe and Moreswe pans, whereas Motailane pan has a seasonal watering hole. In the pans and dry river valleys of central Kalahari soils are mainly clay (Shaw and Thomas 1996; Deacon and Lancaster 1988). The pans indicate concentric bands of vegetation related to various flooding and soils (van Rooyen and van Rooyen 1998). Scholes et al. (2002) reported that salty pans such as Makgadikgadi pan are associated with halophytic shrubs and grasses or are sometimes bare, whereas non-saline areas such as Nxai pan, support sedge and grasslands. In KGR, animals drink water in the pans and mammalian herbivores graze grass Enneapogon desvauxii found in Heliotropium lineare-Enneapogon desvauxii community. According to van Oudtshoorn (2009), grass Enneanpogon desvauxii grows on overgrazed areas and it sprouts rapidly after the first rains (eight day grass). It is also good in protecting soil from erosion (van Oudtshoorn 2009). Springboks (Antidorcas marsupialis) prefer to inhabit this community so that they can easily see predators. Valeix et al. (2009) found that habitat selection by mammalian herbivores was influenced by short-term predation risk and grazers prefer to use grasslands and areas nearby waterholes in Hwange National Park (Zimbabwe). Habitats with dense vegetation cover are risky for the prey because they decrease the ability to detect a predator (Gorini et al. 2012). The plant species in Heliotropium lineare-Enneapogon desvauxii community are trampled by animals and the 
Lori T., Dithogo M.K., Setshogo M.P., Koosaletse-Mswela P. (2019). Bots. J. Agric. Appl. Sci. (Issue 2 - Special): 8-23. ISSN 2661-9008
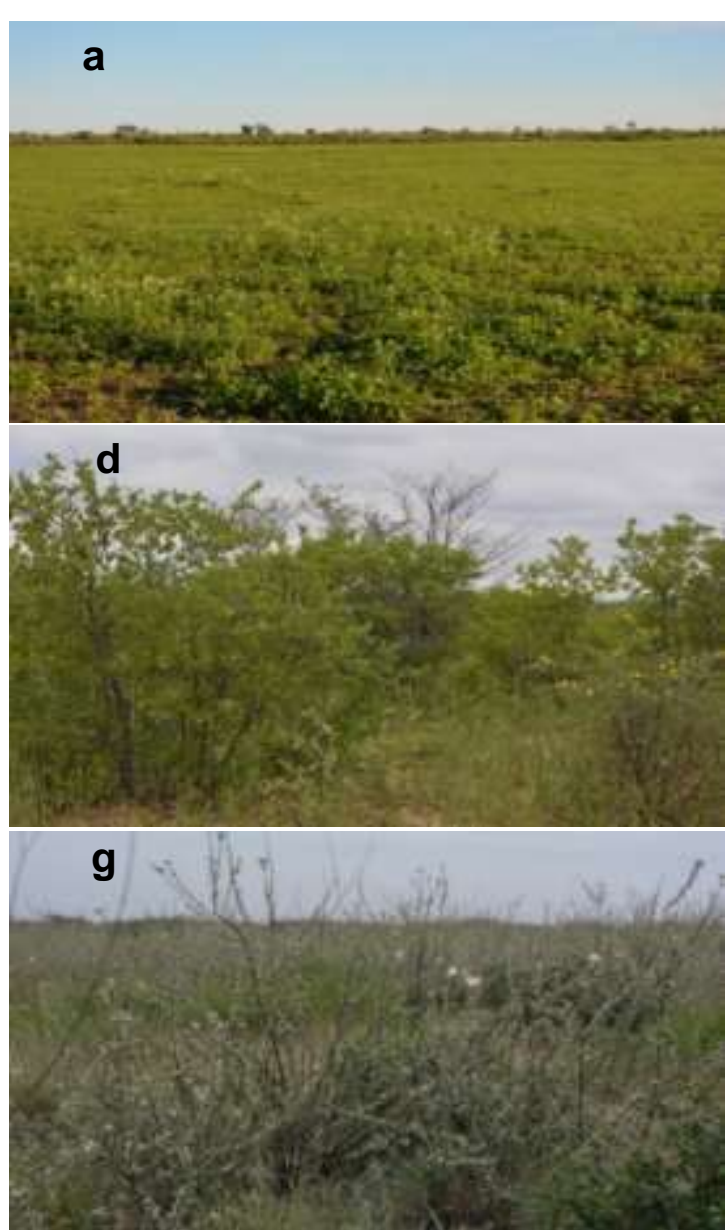

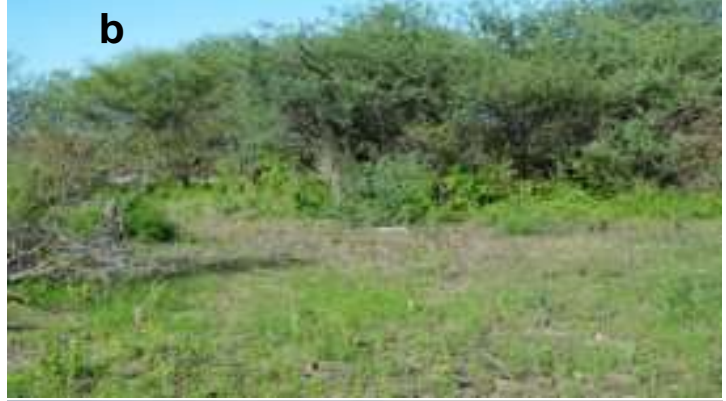

e
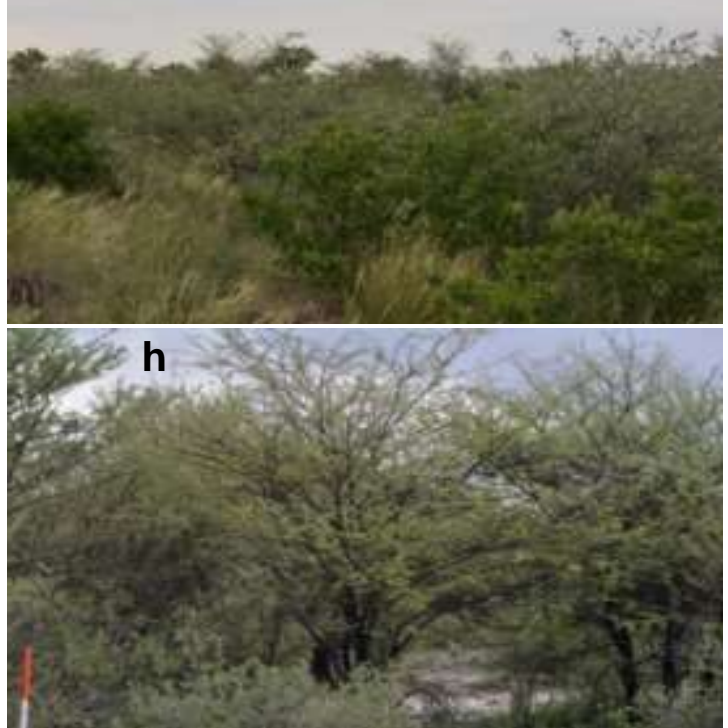

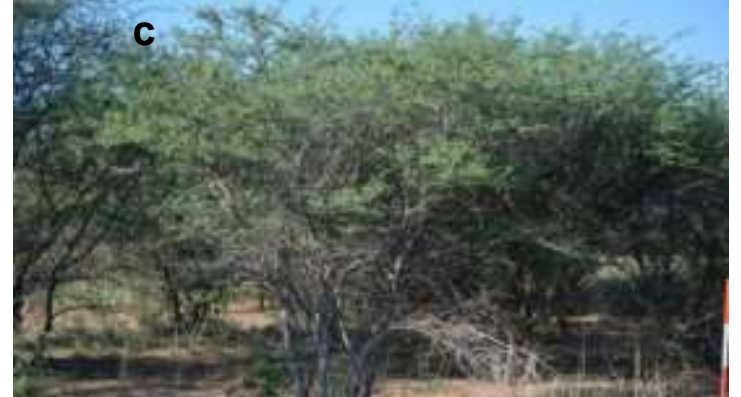

f
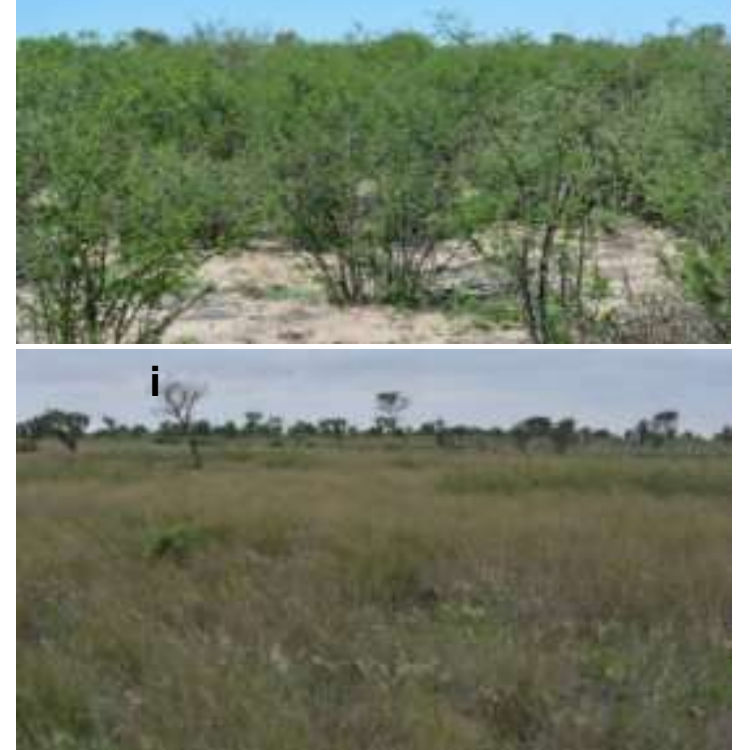

Fig. 3: Plant communities of Khutse Game Reserve and the number of relevés in which photos were taken from: a) Heliotropium lineare-Enneapogon desvauxil community(relevé 67), b) Senegalia mellifera subsp. detinens-Maytenus species community (relevé 68), c) Senegalia erubescens-Philoneptera nelsii community (relevé 38), d) Brachiaria humidicola-Philoneptera nelsii community (relevé 53) e) Terminalia sericea-Philoneptera nelsii community (relevé 56), f) Dichrostachys cinerea-Grewia flava community (relevé 69), g) Catophractes alexandri-Stipagrostis uniplumis community (relevé 44), h) Vachellia luederitzii var.retinens-Grewia flava community (relevé 22) and i) Schmidtia pappophoroides-Stipagrostis uniplumis community (relevé 50). Photos taken by Lori, 2016. 


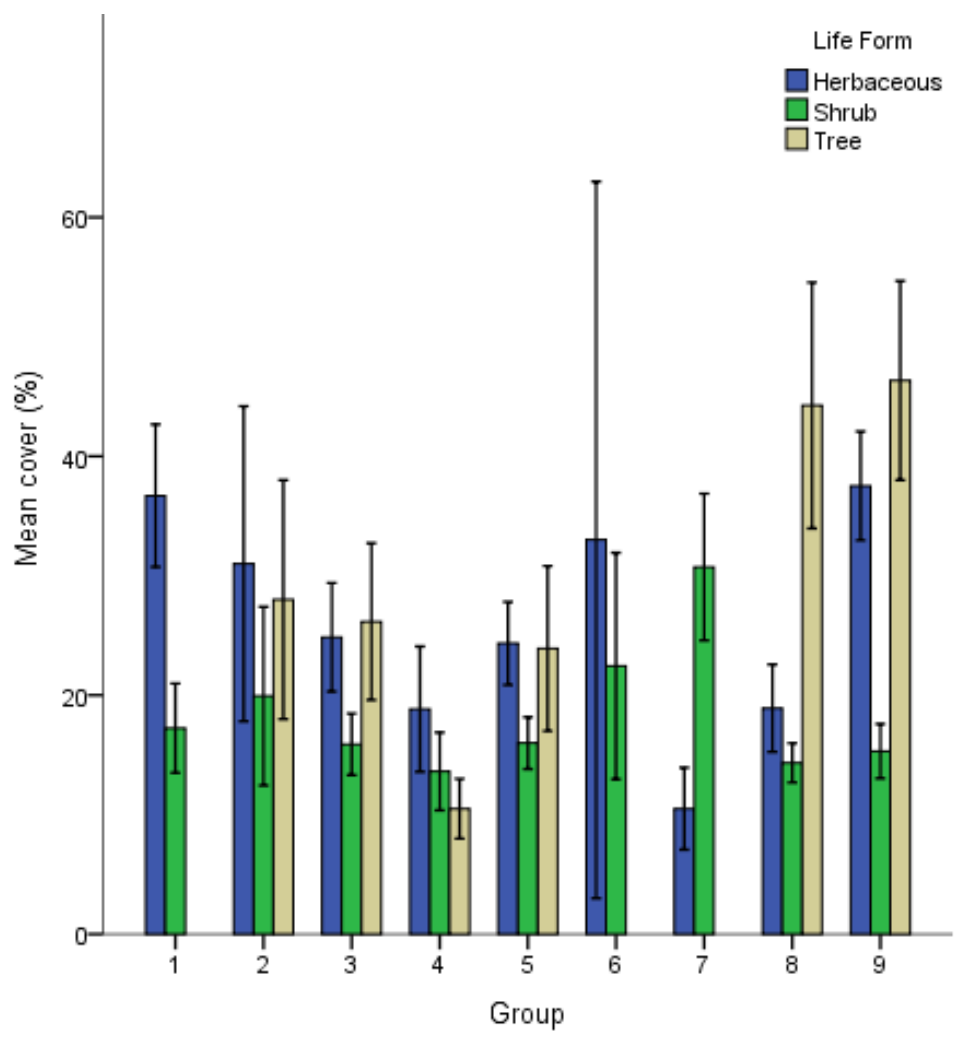

Fig. 4: Mean cover (\%) of herbaceous, shrubs and trees in Khutse Game Reserve plant communities. There are no data for trees in groups 1, 6 and 7. Group numbers represent plant communities which are described in Table 1. Error bars are $\pm 1 \mathrm{SE}$.

pans become bare during dry season because of concentration of animals. Classification of plant communities helps in making ecologically sound decisions on the available habitat for wildlife (Brown et al. 2013).

Senegalia mellifera subsp. detinens-Maytenus species community was a tree island located in pans. This community was very crucial because animals use Senegalia mellifera subsp. detinens trees for shade during hot summer days. Good management of vegetation benefits the wildlife in the reserve and is very crucial to conservation of biodiversity that will influence policies and management practices (West 1993).

The other seven plant communities occured in plain habitat of the reserve. The plain habitat and pans found in KGR are in agreement with DHV (1980). Senegalia erubescens-Philoneptera nelsii community, Brachiaria humidicola-Philoneptera nelsii community and Terminalia sericeaPhiloneptera nelsii community had Philoneptera nelsii as their diagnostic species. Philoneptera nelsii was the most common plant species occuring as both shrub and tree and was found in plain habitat. Dominance of the woody plants agrees with the pattern which has been suggested for savannas in southern Africa (Scholes et al. 2002). Neelo et al. (2013) reported that $P$. nelsii was found in deep sand. Dichrostachys cinerea-Grewia flava community had Dichrostachys cinerea as both diagnostic and dominant plant species. This community was threatened by bush encroachment of shrub Dichrostachys cinerea. An increase in woody plant density leads to thickets that are not penetrable by herbivores thus surpressing palatable grasses and herbs (Wiegand et al. 2006). Catophractes alexandriStipagrostis uniplumis community was found around pans. The shrub Catophractes alexandri was dominant and so dense that it was not easy to penetrate through. An increase in woody plant density leads to thickets that are not penetrable by herbivores thus surpressing palatable grasses and herbs (Wiegand et al. 2006).

Vachellia luederitzii var. retinens-Grewia flava community has Vachellia luederitzii var. retinens as the most common plant species. Vachellia luederitzii var. retinens occured as both trees and shrubs in this community. Schmidtia pappophoroides-Stipagrostis uniplumis community was a grassland mixed with shrubs and trees. Similarly, Wiegand et al. (2006) also reported about grass-dominated areas with interspersed trees, i.e. tree-grass co-existence, in an arid savanna of Namibia. When trees are within the 
grassland, they influence growth under the tree canopy (Furley 2010). During the wet season, trees aid growth of grass by improving nutrient up take and they delay wilting of grass in the dry season (Treydte et al. 2008). Schmidtia pappophoroidesStipagrostis uniplumis community was characterised by grass Stipagrostis uniplumis which occurs throughout the reserve and it is one of the most crucial grazing grasses in sandy semi-arid environments (van Oudtshoorn 2009).

\section{Percentage Cover of Herbaceous, Shrubs and Trees in Plant Communities}

The results showed that there was a statistically significant difference in cover $(\%)$ of herbaceous plants between the different plant communities in plain habitat. This difference was found between Group 9 (Schmidtia pappophoroides-Stipagrostis uniplumis) and Group 3 (Senegalia erubescensPhiloneptera nelsii), Group 4 (Brachiaria humidicola-Philoneptera nelsii), Group 7 (Catophractes alexandri-Stipagrostis uniplumis) and Group 8 (Vachellia luederitzii var. retinens-Grewia flava). The cover (\%) of herbaceous plants in Group 9 differs with other plant communities because this plant community was a grassland with herbaceous layer comprising mainly of the grasses Schmidtia pappophoroides and Stipagrostis uniplumis which were less in cover in other plant communities. The difference in cover (\%) of herbaceous plants between Group 7 (Catophractes alexandri-Stipagrostis uniplumis) and Group 5 (Terminalia sericeaPhiloneptera nelsii) could be due to the fact that Group 7 was dominated by shrub Catophractes alexandri whereas Group 5 was dominated by shrubs and trees of Terminalia sericea and Philoneptera nelsii and the plant species in these two plant communities differered in the way they suppressed herbaceous plants.

According to the results, there was no statistically significant difference in cover $(\%)$ of trees and shrubs between the different plant communities. This could be explained by the fact that in the shrub and tree layers, especially in Groups 3, 4 and 8, the dissimilarities between plant communities are associated with changes in plant species dominance rather than existence of different plant species (DWNP 2003; Mishra \& Crews 2014). Catophractes alexandri-Stipagrostis uniplumis community (Group 7) had the highest cover (\%) of shrubs followed by Dichrostachys cinerea-Grewia flava community because these two plant communities are mainly made up of the shrubs Catophractes alexandri and Dichrostachys cinerea, respectively.

Plant Species Richness, Diversity and Evenness of Plant Communities
The results of this study showed no statistically significant difference in plant species diversity (Shannon-Weiner Index) between plant communities. H' ranges from 1.06 to 1.68 . In Ngamiland district, Neelo et al. (2013) found that the diversity of woody plants was 2.18 and 1.5 in Shorobe and Xobe, respectively. There was a statistically significant difference in plant species richness between the different plant communities. Dichrostachys cinerea community, Senegalia mellifera subsp. detinens-Maytenus species community and Catophractes alexandri-Stipagrostis uniplumis community had lower species richness of 11, 14 and 16, respectively. Vachellia luederitzii var. retinens-Grewia flava community had a highest number (46) of plant species. This plant community also had the highest average Jaccard and Sorensen distances, as well as Simpson Beta-diversity (Table 5). Jaccard and Sorensen similarity indices are used to study the co-existence of species or similarity of sampling sites (Raimundo and Vargas 1996). Higher dissimilarity index implies higher dissimilarity of sampling sites. The results indicated that there was no statistically significant difference in plant species evenness between the different plant communities. Brachiaria humidicola-Philoneptera nelsii community had the highest plant species evenness even though there was no statistically significant difference in plant species evenness between the different plant communities. The evenness values obtained in this study were higher than what Neelo et al. (2013) obtained in Ngamiland District.

\section{Conclusion and Recommendations}

This study presents a first attempt in using phytosociological approach of classifying and describing plant communities in KGR. It classified and described nine plant communities in KGR. Two plant communities Heliotropium lineareEnneapogon desvauxii and Senegalia melliferaMaytenus species were located in the pans. The other seven communities were located in the plain habitat. The different plant communities suggest that KGR is rich in plant diversity despite being in a semi-arid area, with Vachellia luederitzii var. retinens-Grewia flava community having the highest number of plant species. The results from this study will help DWNP to develop an updated and well informed management plan with regards to the different plant communities of the reserve. The research will also be a long term record of the characteristics of the plant species in each plant community. It is recommended that surveys of plant communities in KGR should be performed periodically in order to monitor short and long-term changes in plant species composition over time using the results of this study as a baseline. 


\section{Acknowledgments}

We thank Dr M. Flyman for facilitating the collaboration of this project with DWNP. KGR Park Manager, Mrs O. Dintwe, is thanked for providing us with accommodation during data collection. We appreciate $\mathrm{Mr}$ Babusi Phihelo for field assistance during data collection. The valuable comments of Dr M. Selebatso in improving the methodology are appreciated. The help of $\mathrm{Mr} \mathrm{K}$. Tlalang in interpreting satellite images is acknowledged. $\mathrm{Mr} \mathrm{M}$. Mpalo is thanked for help in producing study area map. The Government of Botswana under the Ministry of Environment, Natural Resources and Tourism (MENT) is thanked for giving us Research Permit No. EWT 8/36/4/XXIX (34). We are thankful to the Office of Research and Development (ORD), University of Botswana, for funding this study.

\section{References}

Bezuidenhout H. (1994). An ecological study of the major vegetation communities of the Vaalbos National Park, Northern Cape. 1. The ThanDroogeveldt section. Koedoe37 (2):19-42.

Bezuidenhout H. (2009). The classification, mapping and description of the vegetation of the Rooipoort Nature Reserve, Northern Cape, South Africa. Koedoe 51(1): 1-25.

Braun-Blanquet J. (1932). Plant sociology, trans. Fuller G.D. \& Conard H. S. McGraw-Hill, New York, US.

Brown L.R., Marais H., Henzi S.P. and Barrett L. (2005). Vegetation classification as the basis for baboon management in the Bourke's Luck Section of the Blyde Canyon Nature Reserve, Mpumalanga. Koedoe 48(2): 71-92.

Brown L.R., du Preez P.J., Bezuidenhout H., Bredenkamp G.J., Mostert T.H.C. and Collins N.C. (2013). Guidelines for phytosociological classifications and descriptions of vegetation in southern Africa. Koedoe55 (1) Art. \#1103, 10 pages.

Chytrý M., Tichý L., Holt J. and Botta-Dukát Z. (2002). Determination of diagnostic species with statistical fidelity measures. Journal of Vegetation Science 13: 79-90.

Chytrý M. and Tichý L. (2003). Diagnostic, constant and dominant species of vegetation classes and alliances of the Czech Republic: a statistical revision. Folia Fac. Sci. Nat. Univ. Masaryk. Brno. Biologia 108: 1-231.

Chytrý M. and Schaminée J.H.J., Schwabe A. (2011). Vegetation survey: a new focus for Applied Vegetation Science. Applied Vegetation Science 14: 435-439.
Daemane M.E., Cilliers S.S. and Bezuidenhout H. (2010). An ecological study of the plant communities in the proposed Highveld National Park, in the peri-urban area of Potchefstroom, South Africa. Koedoe 52(1), Art. \#708, 8 pages.

de Wit P.V. and Nachtergaele F.O. (1990). National soil map of Botswana. FAO, Government of Botswana.

Deacon J. and Lancaster N. (1988). Late Quaternary palaeo-environments of southern Africa.Oxford University Press, Oxford, UK.

Dengler J., Oldeland J., Finkch M., Jansen F., Glockler F., Peete R.K., De Cáceres M., Chytrý M., Ewald J. Oldeland J., Lopez-Gonzalez G., Finckh M., Mucina L., Rodwell J.S., Schaminée J.H.J. and Spencer N. 2011. The Global Index of Vegetation-Plot Databases (GIVD): a new resource for vegetation science. Journal of Vegetation Science 22: 582-597.

DHV (1980). Country Wide Animal and Range Assessment Project. Final Report to the Department of Wildlife, National Parks \& Tourism, Government of Botswana, 7 Volumes. DHV Consulting Engineers, Amersfoort.

DWNP (2003). Central Kalahari Game Reserve and Khutse Game Reserve Management Plan.Department of Wildlife and National Parks, Gaborone, Botswana.

Fulbright T.E. (1996). Viewpoint: a theoretical basis for planning woody plant control to maintain species diversity. Journal of Range Management49: 554-559.

Furley P. (2007). Tropical savannas and associated forests: vegetation and plant ecology. Progress in Physical Geography 31(2): 203-211.

Furley P. (2010). Tropical savannas: Biomass, plant ecology, and the role of fire and soil on vegetation. Progress in Physical Geography 34(4): 563-585.

Gillson L. (2004). Evidence of hierarchical patch dynamics in an east African savanna. Landscape Ecology19: 883-894.

Gorini L., Linnell J.D.C., May R., Panzacchi M., Boitani L., Odden M. and Nilsen E.B. (2012). Habitat heterogeneity and mammalian predatorprey interactions. Mammal Review 42: 55-77.

Huntley B.J. and Walker B.H. (eds.) (1982). Ecology of tropical savannas. Springer-Verlag, Berlin, DE.

Kabelo M. and Mafokate D. (2004). A checklist of Botswana grasses. Southern African Botanical Diversity Network [report No. 24], Pretoria and Gaborone.

Longman Atlas for Botswana (2002). Longman 
Group UK Ltd. CTP Book Printers. ISBN 05820313036.

Makhabu S.W., Marotsi B. and Perkins J. (2002). Vegetation gradients around artificial water points in the Central Kalahari Game Reserve of Botswana. African Journal of Ecology 40: 103109.

Meyer K.M., Wiegand K. and Ward D. (2009). Patch dynamics integrate mechanisms for savanna tree-grass coexistence. Basic and Applied Ecology 10: 491-499.

Mishra N.B. and Crews K.A. (2014). Mapping vegetation morphology types in a dry savanna ecosystem: integrating hierarchical object-based image analysis with Random Forest. International Journal of Remote Sensing 35(3): 1175-1198.

Mishra N.B., Crews K.A., Miller J.A. and Meyer T. (2015). Mapping vegetation morphology types in Southern Africa savanna using MODIS Timeseries Metrices: A case study of Central Kalahari, Botswana. Land 4: 197-215.

Mucina L. and Rutherford M.C. (2006). The vegetation of South Africa, Lesotho and Swaziland. Strelitzia 19. South African National Biodiversity Institute, Pretoria, SA.

Mueller-Dombois D. and Ellenberg H. (1974). Aims and methods of vegetation ecology, Wiley, New York, USA.

Neelo J., Teketay D., Masamba W. and Kashe K. (2013). Diversity, population structure and regeneration status of woody species in dry woodlands adjacent to Molapo farms in northern Botswana. Open Journal of Forestry 3(4) 138151.

Nicholas A.M.M., Franklin D.C. and Bowman D.M.J.S. (2009). Coexistence of shrubs and grass in a semi-arid landscape: a case study of mulga (Acacia aneura, Mimosaceae) shrublands embedded in a fire-prone spinifex (Triodiapungens, Poaceae) hummock grasslands. Australian Journal of Botany 57: 396-405.

Pfotenhauer L. (2009). Travel Companion Kgalagadi/ Central. Botswana Tourism Board. Gaborone, Botswana.

Raimundo R. and Vargas J.M. (1996). The probabilistic basis of Jaccard's Index of similarity. Systematic Biology 45(3): 380-385.

Roleček J., Tichý L., Zelený D. and Chytrý M. (2009). Modified TWINSPAN classification in which the hierarchy respects cluster heterogeneity. Journal of Vegetation Science 20: 596-602.

Schaminée J.H.J., Hennekens S.M., Chytrý M. and
Rodwell J.S. (2009). Vegetation-plot data and databases in Europe: an overview. Preslia 81: 173-185.

Scholes R.J. and Walker B.H. (1993). An African savanna: synthesis of the Nylsvley study. Cambridge University Press, Cambridge, UK.

Scholes R.J., Dowty, P.R. Caylor, K., Parsons D.A.B., Frost P.G.H. and Shugart H.H. (2002). Trends in savanna structure and composition along an aridity gradient in the Kalahari. Journal of Vegetation Science 13: 419-428.

Setshogo M.P. and Venter F. (2003). Trees of Botswana: names and distribution. Southern African Botanical Diversity Network [report no. 18], Pretoria, SA.

Setshogo M.P. (2005). Preliminary checklist of the plants of Botswana. Southern African Botanical Diversity Network [report no. 37], Pretoria, SA.

Shaw P.A. and Thomas D.S.G. (1996). The Quaternary palae-oenvironmental history of the Kalahari, southern Africa. Journal of Arid Environments 32: 9-22.

Skarpe C. (1992). Dynamics of savanna ecosystems. Journal of Vegetation Science 3: 293-300.

Skarpe C. (1996). Plant functional types and climate in a southern African savanna. Journal of Vegetation Science 7:397-404.

Sokal R.R. and Rohlf F.J. (1969). Introduction to Biostatistics. $2^{\text {nd }}$ Edition W.H. Freeman \& Company, New York, pp 776.

Thomas D.S.G. and Twyman C. (2004). Good or bad rangeland? Hybrid knowledge, Science, and local understanding of vegetation dynamics in the Kalahari. Land Degradation Development 15: $215-231$.

Tichý L. (2002). JUICE, software for vegetation classification. Journal of Vegetation Science13: 451-453.

Treydte A.C., van Beeck F.A.L., Ludwig F. and Heitkoenig I.M.A. (2008). Improved quality of beneath-canopy grass in South African savannas: local and seasonal variation. Journal of Vegetation Science 19: 663-670.

Valeix M., Loveridge A.J., Chamaille-Jammes S., Davidson Z., Murindagomom F., Fritz H. and Macdonald D.W. (2009). Behavioral adjustments of African herbivores to predation risk by lions: Spatiotemporal variations influence habitat use. Ecology 90(1): 23-30.

van Oudtshoorn F. (2009). Guide to grasses of Southern Africa. Briza, Pretoria, South Africa.

van Rooyen N. and van Rooyen M.W. (1998). Vegetation of the south-western arid Kalahari: 
an overview. Transactions of the Royal Society of South Africa 53: 113-140.

Weilenmann M., Gusset M., Mills D.R., Gabanapelo T. and Schiess-Meier M. (2010). Is translocation of stock-raiding leopards into a protected area with resident conspecifics an effective management tool? Wildlife Research 37: 702707.

West N.E. (1993). Biodiversity of Rangelands. Journal of Range Management 46(1): 2-13.

Wiegand T., Jeltsch F., Hanski I. and Grimm V. (2003). Using pattern-oriented modelling for revealing hidden information: a key for reconciling ecological theory and application. Oikos 100: 209-222

Wiegand K., Ward D. and Saltz D. (2005). Multiscale patterns and bush encroachment in an arid savanna with a shallow soil layer. Journal of Vegetation Science 16: 311-320.

Wiegand K., Saltz D. and Ward D. (2006). A patchdynamics approach to savanna dynamics and woody plant encroachment-Insights from an arid savanna. Perspectives in Plant Ecology, Evolution and Systematics 7: 229-242.

Wikum D.A. and Shanholtzer G.F. (1978). Application of the Braun-Blanquet coverabundance scale for vegetation analysis in land development studies. Environmental Management 2(4): 323-329.

Woldewahid G., van der Werf W., Sykora K., Abate T., Mostofa B. and van Huis A. (2007). Description of plant communities on the Red Sea coastal plain of Sudan. Journal of Arid Environments 68: 113-131.

Zehnder A. (2015). Home range analyses and kill site detection of lions and leopards in the Kalahari, Botswana. MSc Dissertation, University of Zurich, Winterthurerstrasse, Zurich.

Zietsman M.M. and Bredenkamp G.J. (2006). Dune vegetation and coastal thicket plant communities in threatened Limestone Fynbos of Andrew's Field and Tsaba-Tsaba Nature Reserve, Struisbaai, Western Cape. Koedoe 49(1): 33-47. 